Global Conferences Series:

Social Sciences, Education and Humanities (GCSSSEH), Volume 2, 2019

The $2^{\text {nd }}$ International Conference on Sustainable Development \& Multi-Ethnic Society

DOI: https://doi.org/10.32698/GCS.0196

\title{
The Readiness of History Teacher in Implementing Classroom Assessment
}

\author{
Sawai Pilok ${ }^{1}$, Abdul Razak Ahmad ${ }^{2} \&$ Mohd. Mahzan Awang ${ }^{3}$ \\ ${ }^{123}$ Faculty of Education, MALAYSIA \\ E-mail: $\underline{\text { sawaipilok2017@gmail.com }}$
}

\begin{abstract}
This concept paper will discuss the readiness of History teacher in implementing classroom assessment in the national secondary schools. Classroom assessment is a standard medium applied by Education Ministry to measure the development of students' holistically. $21^{\text {st }}$ century History teachers need to equip themselves with higher order of skills in pedagogy, mastery of syllabus, the latest technology, learning psychology and understanding of students' development whilst caring for their needs, thus as assessor for their students'. History teacher needs to install themselves with a certain level of knowledge, skill and attitude in order to achieve the Malaysia Education Standard of Quality (SKPM). Implementation of classroom assessment needs teachers to apply various methods and techniques in order to achieve interesting and fun learning activities. This concept paper will also discuss several recommendations to increase the level of readiness among History teacher in implementing effective classroom assessment. The recent changes in Malaysia educational system, mainly in the explosion of technology and global communication, have been seen as big challenge for History teachers in ensuring an effective, adaptive and ongoing classroom assessment in various level of knowledge. Therefore, History teacher needs to put more effort in developing and delivering knowledge and information to their students and be prepared to adapt and inculcate the various $21^{\text {st }}$ century teaching methods and techniques in their lesson and assessment.
\end{abstract}

Keywords: readiness, history teachers, classroom assessment, $21^{\text {st }}$ century teaching and learning

\section{Introduction}

The world of education has undergone changes as a result of information and communication technologies that have affected the lives of the global community. This phenomenon has led the Malaysian Education Development Plan 2013-2025 (PPPM 2013-2025) with the aim of producing quality, holistic and marketable generations aligned the Fourth Industrial Revolution (4IR). Based on the 2013-2025 PPPM that outlines student assessment through School Based Assessment (PBS) as a holistic assessment benchmark. School-Based Assessment (PBS) was introduced in the late 2011 which is a holistic assessment of student achievement levels. PBS comprises two categories, academic and nonacademic. The PBS academic category consists of two 
components: Central Assessment (PP) and School Assessment (PS). While the non-academic category also comprises two components, Physical Activity, Sport and Co-Curricular Assessment (PAJSK) and Psychomotor Assessment (PPsi) as in the Examination Board Release Letter. 3 of 2011 (KPM 2018).

School Assessment (PS) is now known as Classroom Assessment and will be used by the end of 2016 and retaining the existing concept of School Assessment. The concept of classroom assessment is an on-going assessment process that enables teachers to gather information on student development, progress and mastery of the Content Standards and Learning Standards as stated in the Curriculum and Assessment Standard Document (DSKP) of each subject. Classroom assessment is the process of collecting, analysis, synthesizing, interpreting the whole information as continuous reflection on teaching and learning which consistently judging the betterment of teaching and learning process. Implementing proper assessment will give a clear picture of student mastery of the Learning Standards set in the curriculum. Student mastery in each subject thorough, objective and focused classroom assessment starting in 2019 with abolition and $1^{\text {st }}, 2^{\text {nd }}$ and $3^{\text {rd }}$ year student exams. Meanwhile, in the Secondary Level, Form Three Assessment is no longer fully exam oriented this the effectiveness of the classroom assessment will be achieved by 2020. All the information gained from the assessment is not meant for competition between students. Instead, it is used by teachers and parents for follow-up enrichment activities to improve student achievement. Teachers play an important role in implementing classroom assessment and need to set learning objectives based on the Learning Standard to assess, design and build assessment instruments, carry out assessment, record assessment results, analysing assessment, analysing assessment information, reporting and follow up (KPM, 2018).

History teachers need to be fully prepared with the skills and knowledge of implementing classroom assessment. A positive attitude and keep up with the current educational changes are highly demanded by History teachers. The rapid use of communication technology poses a great challenge for teachers to perform tasks responsibly quickly good results. Effective teachers are teachers who always ready with quality teaching to produce quality and competitive students. Teachers readiness for change in the educational world requires teacher strength in terms of teacher knowledge, skills and positive attitude. Readiness is process that involves integrating one's physical, mental and emotional aspects into action. Effective teaching and assignments depends on the maturity and experience of the teacher. According to Waermkuth, Edward \& Richmond (2000), readiness in a teacher context means a teacher's willingness to assume responsibility that includes interests, attitudes, knowledge and skills.

According to the Curriculum Division of the Ministry of Education Malaysia (2015), history subject are the core subjects of the Secondary School Curriculum (KSSM) that students must study continuously from Form One to Form Five. History of secondary school history integrated the areas of Knowledge Content, History Thinking Skills (KPS), Citizenship Elements and Civic Values. The main focus of the History Society is to produce students who are knowledgeable and historyaware and can contribute to a competitive society in the future therefore a more systematic approach classroom assessment is compulsory effective 2019. History teachers need to prepare themselves with knowledge and skills as assessors and classroom assessment, producing more students who can master the skills needed in the $21^{\text {st }}$ century. Ekua Teyiwa (2016), stated that assessment is about learning and the importance of teaching and learning activities in schools as well the interaction of teachers and students to obtain information that can be used as an effort to improve the teaching and learning process.

\section{Problem of Statement}

1. History teachers lack the knowledge and skills for implementing classroom assessment in the $21^{\text {st }}$ century teaching and learning.

2. History teachers are not good practitioners of classroom assessment in the teaching and learning process.

\section{Objectives of Concept Paper}

1. To increase the readiness of History teachers in implementing classroom assessment.

2. To improve the skills and knowledge of History teachers as assessors or assessors of the classroom.

3. To encourage history teacher readiness for the change in the national education system. To increase the readiness of History teachers in implementing classroom assessment.

\section{Theory}

Teacher readiness in implementing classroom assessments supports the Theory of Needs that motivates 
teachers to strive for excellence in the teaching and learning process. The theory of necessity was popularized by important figures such as Abraham Maslow, McClelland and Herzberg (Ainon \& Abdullah, 2002). According to Mok Soon (2010), the effectiveness of teaching and learning in the classroom depends on the extent to which students' needs are met, fun and able to enhance their knowledge. Teachers' skills in designing teaching and learning activities can help pupils to be more motivated by their potentials and strengths. Implementing the concept of need in conducive classroom practices as well as caring teachers makes students feel comfortable, happy, and safe.

\section{Discussion}

Classroom assessment is an ongoing process of teaching and learning sessions aim at information on the development, ability and mastery of the curriculum objectives to be achieved. According to Laura (2007), classroom assessment facilitates the transformation of a student-centred environment with an emphasis on student perspectives, their diverse learning styles, and intellectual development. The assessment was conducted by subject who taught in the classroom during the teaching and learning process, and designed the instrument used, developed the items, administered, ordered, analysis, recorded and reported student performance. Therefore, the selection of classroom assessment activities should be used based on the suitability and level of student achievement in classroom. History teacher need to study the appropriateness of assessment activities in order to attract interest among student in learning and applying historical values successfully.

In conducting classroom assessments, History teachers should have practical knowledge of the teaching and learning process and assessment. Changing student's achievement level requires teachers who are knowledgeable, skilled and prepared for the transformation of national education. According to Suresh Kumar (2015), if we are to enrich the quality of knowledge, the transformation of mind must be experienced by teachers first in renewing their thinking, mastering the ability to work on quality knowledge and translating the value of knowledge by students in the classroom. Classroom assessment was implemented in an effort to bring the Education Curriculum into the 20132025 PPPM that requires knowledge and multidimensional History teachers. Fullan (2015), emphasized that teachers need to improve their ability to cope with changes in education because if they fail, they will be continuously pressure by merciless external change with that in mind. As crush, History teachers need to be more open and prepared for changes in the curriculum and education system, thus developing the potential and professionalism of the country teaching.

In addition, in the Curriculum and Assessment Standard Document (KPM, 2018) the skills of History teachers in performing classroom assessment require teachers to constantly plan lessons, select appropriate teaching instruments, and evaluate regularly. According to Abdul Said \& Shanti (2017), teacher readiness is essential order to prepare well for each lesson to enable the assessment to be holistic as well as for teachers to see student progress and achievement individually. History teachers need to plan a week preparation for effective classroom assessment. According to Noorzeliana, Norazilawati \& Danish (2017), teachers are the leading parties in the assessment, so the quality of classroom assessment is to obtain information about a student's progress and achievement. In the classroom assessment teachers should have an attitude of constantly engaging in various activities such as writing test and performance assessment result in decision making (KPM, 2018).

The revolution in the world of global education emphasizes the generation of mastering $21^{\text {st }}$ century skills with creative, critical, and innovative skills. Through the classroom assessment teachers are able to inculcate $21^{\text {st }}$ century teaching and learning styles, which in turn produce globally competitive and comparable students international. However, not all History teachers in our country have high skills and knowledge in information and communication technology. For senior History teachers the use of technology poses a great challenge for them in teaching and learning process in the classroom. The ability of teachers to master the use of technology and communication influences the quality of teaching. Senior History teachers need to be openminded and equip themselves with latest pedagogy and knowledge, to assist teachers in implementing classroom assessments effectively. However not all Malaysian secondary schools have good Internet access and adequate facilities to meet the demands of information and communication technology in education. This constraint hinders the level of readiness among teachers to implement classroom assessment more effectively.

\section{The Importance of History Teachers Readiness}

History teacher readiness with the latest assessment methods can provide feedback on student achievement levels without relying entirely on exams. Through 
classroom assessment History teacher can enhance their skills and practices in teaching and learning. History teachers can build new innovations in their methods by implementing effective classroom assessments. Shaari (2008), describing effective teaching as the ability of teaching as ability of teachers to convey teaching information well, is effective and this will motivate students to continue to excel in success. According to Hussain (2008), classroom assessment can enhance students' interest as the activities provided provide a good learning environment for the students to be more interested in their influence student achievement levels. History teachers not only produce quality students through effective classroom assessment but also a merit for teachers in line with KPM's aspiration to become 21 st century teachers.

Furthermore, the availability of history teachers with high knowledge and skill is essential in implementing classroom assessments to boost teachers professionalism as a transformation agent in the education world. According to study of Safarin \& Nur Hidayah (2014), teachers 'readiness to rely on teachers' knowledge of concept and implementation assessment can enhance student achievement an improve assessment of teaching and learning activities. According to Ainon \& Abdullah (2002), correct information and knowledge are form of power. Jamilah (2006), points out that effective teachers are constantly developing skills in teaching so that teaching is beneficial to students. History teachers, therefore, need to complement their fracture with pedagogy and mastery of teaching content to respond to the challenges of the current educational world. History teachers must always be prepared and positively accepting the curriculum transformation of the education system and upholding the National Philosophy of Education.

\section{Recommendations}

In enhancing the readiness of History teachers to conduct classroom assessment there is needs to revise the concept of classroom assessment for History subject as well as simplify their operations more systematically and effectively. With a large number of students in secondary schools, it is difficult for teachers to assess their effectively and correctly. This situation puts pressure on History teachers in high school classroom assessment. The issue of school workload has been widely discussed and researched but has not been fully resolved. It is of concern that classroom assessment is not fully implemented by History teachers will have a disastrous effect on the new generation of mastering, understanding historical facts and cherishing historical values. If the concept of assessment is simpler and less burdensome for teachers, the implications for teachers will be more focused on continuing to implement, classroom assessment effectively and loving their students.

Furthermore, classroom assessment is most effective when History teachers themselves are given the freedom to formulate and select assessment activities based on school suitability, student background, location and culture of student life at their school level. Sharing knowledge among teachers by formulating activities to produce a history-based classroom assessment module can help enhance teaching and learning effectiveness. History teachers will be more confident in carrying out their teaching and learning activities with unwavering enthusiasm and without restraint. The MOE should rethink the curriculum that appropriate for students according to the current needs and lifestyles of the students and allow teachers to formulate their own curriculum and activities at school level so that they are not overly depends and tied to existing syllabus. The interest and enthusiasm of the students in mastering the various fields of knowledge should be built through a curriculum that meets the present and future needs. Thus, the freedom of History teachers to formulate modules and to choose classroom assessment activities at school level can enhance the knowledge, skills, confidence in producing History teachers.

\section{Conclusion}

Teachers with good knowledge, skill and attitudes helps the implementation classroom assessment effectively. History teachers still need guidance and motivation to become cream of the crop. Highly competitive and confidence need to be instil in each History teachers to uphold the teaching profession. The teaching and learning of History teachers should be enhanced to a higher level, ready to cope with the changing technologies of communication and $21^{\text {st }}$ century life. Naturally, History teachers not only rely on workshops and courses provide by other ministries or agencies to be creative, critical and more innovative but are constantly learning new science and technology in an effort to realize the aspirations of national education. History teachers can be develop more efficient and practical in planning, managing and handling classroom assessment modules to produce students with high-level thinking skills as $21^{\text {st }}$ century learning should be practiced.

\section{References}


[1] Abdul Said \& Shanti Gobalakrishnan. 2017. Tahap Integriti dan Kesediaan Guru Dengan Pelaksanaan Pentaksiran Berasaskan Sekolah. International Journal of Education, Psychology and Counselling, 2 (4): 1-22.

[2] Ainon Mohd. \& Abdullah Hassan. 2002. Guru Sebagai Pendorong Dalam Darjah. Pahang: PTS Publications \& Distributors Sdn. Bhd.

[3] Ekua Teyiwa Amua-Sekyi. 2016. Assessment, Student Learning and Classroom Practice: A Review. Journal of Education and Practice. 7 (21): 1-6.

[4] Fullan, M. 2015. Makna Baharu Perubahan Pendidikan. Terj. Kasturi Isan \& Aziah Salleh. Kuala Lumpur: Institusi Terjemahan \& Buku Malaysia.

[5] Hussain Alkharusi. 2008. Effect of Classroom Assessment Practices on Students' Achievement Goals. Journal Education Assessment, 13 (4): 243266.

[6] Kementeri Pendidikan Malaysia. 2018. Panduan Pentaksiran Bilik Darjah. Putrajaya: Bahagian Pembangunan Kurikulum.

[7] Laura Mueller. 2007. Classroom Assessment. Journal of Security Education, 2: 47-53.

[8] McMillan, J. H. 2011. Classroom Assessment: Principles and Practice for effective instruction. United States of America Pearson Education, Inc.

[9] Mohd Safarin \& Nur Hidayah Ismail. 2014. Kesediaan Guru Terhadap Pelaksanaan Pentaksiran Berasaskan Sekolah Bagi Mata Pelajaran Kemahiran Hidup Bersepadu. International Seminar Teaching and Vocational Education 2014 (TVEIS 2014): 475483.

[10] Mok Soon Sang. 2010. Pengurusan Pengajaran dan Pembelajaran. Selangor: Multimedia-ES Resourcee Sdn. Bhd.

[11] Noorzeliana Idris, Norazilawati Abdullah \& Saniah Sembak. 2017. Isu dan Cabaran Pentaksiran Berasaskan Sekolah Dalam Kalangan Guru. Universiti Sultan Idris.

[12] Shaari. 2008. Guru Berkesan: Petua dan Panduan. Sintok. Penerbitan Universiti Utara Malaysia.

[13] Suresh Kumar N Vellymalay. 2015. Guru Hebat Penjana Transformasi Pendidikan Negara. Kuala Lumpur: Dewan Bahasa dan Pustaka. 